J. Dairy Sci. 98:5529-5544

http://dx.doi.org/10.3168/jds.2014-9016

(C) American Dairy Science Association ${ }^{\circledR}, 2015$.

\title{
The effect of high and low levels of supplementation on milk production, nitrogen utilization efficiency, and milk protein fractions in late-lactation dairy cows
}

\author{
M. Reid, ${ }^{*} \dagger$ M. O’Donovan, ${ }^{*}$ J. P. Murphy, ${ }^{*}$ C. Fleming, ${ }^{*}$ E. Kennedy, ${ }^{*}$ and E. Lewis ${ }^{* 1}$ \\ ${ }^{*}$ Teagasc, Animal \& Grassland Research and Innovation Centre, Moorepark, Fermoy, Co. Cork, Ireland \\ †Institute of Global Food Security, Queen's University Belfast, Stranmillis Road, Belfast, BT9 5AY, UK
}

\begin{abstract}
To fill the feed deficit in the autumn/late lactation period in a seasonal grazing system, supplementation is required. This study aimed to investigate the use of baled grass silage or concentrate as supplementation to grazing dairy cows in late lactation. Eighty-four grass-based spring-calving dairy cows, averaging 212 $\mathrm{d}$ in milk, were allocated to 1 of 6 treatments [high grass allowance (HG), low grass allowance (LG), grass with a low concentrate allocation (GCL), grass with a low grass silage allocation (GSL), grass with a high concentrate allocation $(\mathrm{GCH})$, and grass with a high grass silage allocation (GSH)] to measure the effects of using baled grass silage or concentrate as supplements to grazed grass. Effects on intake, milk yield, milk composition and $\mathrm{N}$ fractions, and $\mathrm{N}$ utilization efficiency were measured. Treatments HG and LG received 17 and $14 \mathrm{~kg}$ of dry matter (DM) grass/cow per d, respectively. Treatments GCL and GSL were offered $14 \mathrm{~kg}$ of DM grass/cow per d and $3 \mathrm{~kg}$ of DM of supplementation/cow per d. Treatments GCH and GSH were offered $11 \mathrm{~kg}$ of DM grass/cow per d and $6 \mathrm{~kg}$ of DM of supplementation/cow per d. Milk yield was greatest in the GCH treatment and milk solids yield was greatest in both concentrate-supplemented treatments. The HG and LG treatments excreted a greater quantity of $\mathrm{N}$ as a proportion of $\mathrm{N}$ intake than the supplemented treatments. The HG treatment also excreted the greatest total quantity of $\mathrm{N}$. This indicates an improvement in $\mathrm{N}$ utilization efficiency when supplementation is offered compared with grazing only. Offering $6 \mathrm{~kg}$ of DM of either grass silage or concentrate as supplementation decreased milk true protein concentration compared with offering a grass-only diet. This suggests that increasing the proportion of supplementation relative to grass may negatively affect milk processability, which is associated with milk true protein concentration.
\end{abstract}

Received October 25, 2014.

Accepted April 12, 2015.

${ }^{1}$ Corresponding author: Eva.lewis@teagasc.ie
Key words: nutrition, grass silage, grass, concentrate, nitrogen, milk protein

\section{INTRODUCTION}

The ability to grow between 10 and $16 \mathrm{t}$ grass DM/ ha gives a competitive advantage because, in countries such as Ireland, grass is the cheapest feed source for milk production (Finneran et al., 2010). Seasonal grass growth patterns lead to deficits in the spring and autumn. When grass supply is limited, the grass-based diet of the dairy cow must be supplemented to ensure that cow nutritional requirements are met to extend the lactation at a low cost. Supplements such as grass silage and concentrates are commonly used to fill the feed deficit that arises when grass supply is limited (Kennedy et al., 2005).

Grass silage is the most important feed source available to Irish dairy cows after grazed grass (Finneran et al., 2010). Recent innovations in grassland management involve the preservation of grass as baled silage during times of grass surplus in the main grazing season. Baled grass silage can therefore be used as a tool to manage surplus grass and grass utilization. Grass silage bales are often made from higher quality grass than the conventional method of ensiling grass in a pit (McEniry et al., 2011). The effect on milk yield and milk composition of offering grass silage as a supplementary feed to grazing dairy cows in late lactation has been investigated with varying results. A review by Phillips (1988) concluded that offering grass silage to cows offered a grass-based diet in late lactation increased milk yield, decreased milk fat concentration, and had variable effects on milk protein concentration compared with grass-only diets. The experiments considered in the review all used grass silage, which was ensiled in a pit. O'Brien et al. (1996) investigated the effect of varying levels of grass silage and concentrates as supplementation to spring-calving grass-based dairy cows in late lactation; they concluded that supplementation with silage caused a linear decline in milk solids yield. Milk yield and milk solids yield were increased linearly 
with increasing concentrate supplementation. Grass was grazed to a target postgrazing sward height of 6 to $7 \mathrm{~cm}$, which is substantially greater than the current recommendation of 4 to $4.5 \mathrm{~cm}$. The grass silage used in the study was also from a pit.

Concentrate is often used as a supplement in late lactation. Although concentrate is more expensive than grass silage, the milk response (MR) to concentrate is greater than the MR to grass silage (Peyraud et al., 2004). Feeding supplementary concentrate to late lactation cows in autumn is also recommended to maintain milk lactose concentration above the target of $42.0 \mathrm{~g} /$ kg (O'Brien, 2008).

Researchers are interested in improving the nitrogen utilization efficiency (NUE) of dairy cows to reduce the $\mathrm{N}$ excreted in urine (Peyraud et al., 2004). Urinary $\mathrm{N}$ is the primary route for urea excretion (Spek et al., 2013). Olmos Colmenero and Broderick (2006) showed that the concentration of $\mathrm{N}$ in urine is directly related to the diet. Urine $\mathrm{N}$ excretion can be high in grassbased diets due to the high dietary protein concentration (Dijkstra et al., 2013).

Milk processability, which is the suitability of milk for processing into dairy products, can be improved by increasing particular $\mathrm{N}$ components in the milk, specifically CN (Hermansen et al., 1999). Casein concentration in milk is closely related to the diet of the dairy cow and can be increased with increases in both dietary CP and energy (Sutton et al., 1996).

Few data are available in the literature on the effect of including high-quality baled grass silage, in comparison with concentrate, in the diet of grazing dairy cows in late lactation in autumn. The effects on dairy cow $\mathrm{N}$ excretion and on the protein parameters in milk that effect milk processability are lacking. The objective of the current study was to measure the effects of offering different supplementary feeds to grazing dairy cows in late lactation on milk yield and composition, NUE, and milk $\mathrm{N}$ fractions. We hypothesized that when supplementary feeds were offered with a low allowance, grass-only diet $(14 \mathrm{~kg}$ of $\mathrm{DM}>4 \mathrm{~cm})$, the milk and milk solids yield response would be positive. We also hypothesized that using concentrate as the supplement would result in a greater milk yield response than grass silage. Finally, we hypothesized that using a larger allocation of grass, compared with grass silage supplementation, would give a greater milk and milk solids yield response.

\section{MATERIALS AND METHODS}

The experiment was conducted at Teagasc, Animal and Grassland Research and Innovation Centre, Moorepark, Fermoy, County Cork, Ireland $\left(50^{\circ} 09^{\prime} \mathrm{N}\right.$, $8^{\circ} 16^{\prime} \mathrm{W}, 35 \mathrm{~m}$ above sea level). The area used was under permanent pasture with a predominantly perennial ryegrass (Lolium perenne L.) sward. The grass sward was composed of 50\% Astonenergy and 50\% Tyrella cultivars. The average age of the pasture was 4 yr. Prior approval for animal use was attained from the Teagasc Animal Ethics Committee (Ref-TAEC 14/2013) and the Irish Medicines Board (Ref-AE19132/P001).

The experiment was a complete randomized block design and was conducted between September 30 and November 16, 2013. Eighty-four lactating dairy cows (66 multiparous and 18 primiparous) at, on average, 212 DIM ( $\mathrm{SD}=23 \mathrm{~d}$ ) were selected from the Teagasc Moorepark spring-calving dairy herd. The average calving date of the cows was March 2, 2013 (SD = 23 d). Prior to the beginning of the study, cows were offered $16 \mathrm{~kg}$ of DM grass/cow per d and no concentrate.

\section{Treatments and Grazing Management}

The cows were blocked based on DIM, lactation number $(3 \pm 1.3$; mean $\pm \mathrm{SD})$, milk yield $(19 \pm 3.1$ $\mathrm{kg}$ of milk/cow per day), milk protein concentration $(37.0 \pm 2.7 \mathrm{~g} / \mathrm{kg})$, milk solids yield $(1.6 \pm 0.21 \mathrm{~kg})$, BW $(525 \pm 54 \mathrm{~kg})$, and BCS $(3.2 \pm 0.28 ; 1-5$ scale of Edmonson et al., 1989). From within block, cows were randomly assigned to 1 of 6 feeding treatments: high grass allowance only (HG), low grass allowance only (LG), grass with a low concentrate allocation (GCL), grass with a low grass silage allocation (GSL), grass with a high concentrate allocation $(\mathbf{G C H})$, and grass with a high grass silage allocation (GSH). Treatments $\mathrm{HG}$ and LG received 17 and $14 \mathrm{~kg}$ of DM grass/cow per d, respectively. Treatments GCL and GSL were offered $14 \mathrm{~kg}$ of DM grass/cow per d and $3 \mathrm{~kg}$ of DM of supplementation/cow per d. Treatments GCH and GSH were offered $11 \mathrm{~kg}$ of DM grass/cow per d and $6 \mathrm{~kg}$ of DM of supplementation/cow per d. Fresh grass was offered daily. The GCL and GCH treatments received their concentrate allocation in 2 equal measures during morning and afternoon milkings via the Dairymaster feed delivery system (Dairymaster, Causeway, Co. Kerry, Ireland). The grass silage was offered on an outdoor feeding pad. A self-locking stall swing (O'Donovan Engineering, Coachford, Co. Cork, Ireland) was used to secure cows within the GSL and GSH treatments and ensure that they received the correct grass silage allocation. Treatment GSL had approximately $1 \mathrm{~h}$ to consume their supplementary feed. Treatment GSH had approximately $1 \mathrm{~h} 30 \mathrm{~min}$ to consume their supplementary feed. The DM of the grass silage was assessed 6 times per week to calculate the daily fresh weight grass silage allocation per cow per day. Samples of the grass silage bale were taken the day before feeding, 
and a subsample of $0.1 \mathrm{~kg}$ was dried at $90^{\circ} \mathrm{C}$ for $16 \mathrm{~h}$ for DM estimation. During each day of the study, any grass silage not eaten by the cows within the GSL and GSH treatments was weighed back and a sample taken for DM estimation to assess individual cow daily grass silage intake. Feed troughs in the milking parlor were checked daily for any concentrate not eaten, and the refusals were collected and weighed.

The experimental grazing area consisted of 30.39 ha divided into 15 individual paddocks with permanent fences. Treatment groups grazed adjacent to one another in the same paddocks and were separated using a temporary electric strip-wire fence. The size of the area allocated to each treatment was determined by calculating the pregrazing herbage mass. The pregrazing herbage mass $(>4 \mathrm{~cm})$ was determined twice weekly by cutting 4 strips of grass per paddock $(1.2 \mathrm{~m} \times 10 \mathrm{~m})$ using an Etesia mower (Etesia UK Ltd., Warwick, UK). Ten measurements of compressed sward height were taken pre- and postcutting using a rising plate meter (diameter $355 \mathrm{~mm}$; Jenquip, Feilding, New Zealand). All mown grass from each cut was weighed and then a sample was collected $(\sim 0.3 \mathrm{~kg})$. A subsample of $0.1 \mathrm{~kg}$ was dried at $90^{\circ} \mathrm{C}$ for $16 \mathrm{~h}$ for DM estimation. Pre- and postgrazing sward height was assessed daily using a Jenquip rising plate meter. Pre- and postgrazing sward heights were measured by taking 50 measurements/ treatment per d.

Once weekly, $24 \mathrm{~h}$ before grazing, grass samples were collected from each treatment grazing area to determine the quality of the grass offered. Following close observation of the treatment groups, grass was cut using a Gardena hand shears (Husqvarna AB, S-561 82 Huskvarna, Sweden) to heights similar to the postgrazing heights of the individual treatments. Cuts were taken $(\mathrm{n}=20)$ at 5 -m intervals across the diagonals of each treatment paddock. Samples were immediately frozen once collected. Samples were freeze-dried, milled, and passed through a 1-mm sieve (Cyclotech 1093 sample mill, Foss Electric, Hillerød, Denmark) in preparation for chemical analysis. Once weekly, grass silage samples were taken for analysis of chemical composition. Samples were collected with a silage core. Once every $2 \mathrm{wk}$, samples of concentrate were collected for analysis of chemical composition.

\section{Chemical Analysis}

The CP concentration of the grass samples was determined using a Leco N Analyzer (Leco FP-528, Leco Corporation, St. Joseph, MI). Ash was calculated by placing the samples in a Gallenkamp muffle furnace size 3 (Thermo Fisher Scientific Inc., Waltham, MA) for $16 \mathrm{~h}$ at $500^{\circ} \mathrm{C}$. Neutral detergent fiber concentration was analyzed using the Ankom Fiber Analyzer (Ankom Technology Corporation, NY) using procedures determined by Van Soest et al. (1991). The samples were analyzed for OM digestibility (Fibertec Systems, Foss, Ballymount, Dublin, Ireland) using the neutral detergent cellulase in vitro method of Morgan and Stakelum (1987). Silage samples were analyzed immediately after collection for CP, NDF, ash, DM digestibility, and OM digestibility by near infrared reflectance spectroscopy (NIR; Foss-NIR System DK). Concentrate samples were analyzed for CP, NDF, ash, and starch by NIR.

\section{Animal Measurements}

Milking took place daily at 0700 and $1500 \mathrm{~h}$. Individual milk yields were recorded during milking (Dairymaster, Causeway, Co. Kerry, Ireland). Milk fat, milk protein, milk lactose, MUN, and milk CN concentrations were determined weekly from 1300 and $0100 \mathrm{~h}$ sample taken on successive days. Milk composition was analyzed using a Milkoscan 203 (Foss Electric DK). Milk solids yield (kg) was calculated by summing milk fat and protein yields. Solids-corrected milk yield was calculated using the equation of Tyrrell and Reid (1965).

During wk 3, 5, and 7, milk samples were collected from a successive p.m. and a.m. milking. Milk samples collected were proportional to the milk yield of each cow. The individual milk samples from each of the 2 milkings were composited per treatment, giving composite samples for each treatment.

From the composite milk samples, approximately 500 $\mathrm{mL}$ per treatment was used for detailed wet chemistry of $\mathrm{N}$ fractions. This included total milk protein percentage, nonprotein $\mathrm{N}$, and noncasein $\mathrm{N}$. These were measured using the Kjeldahl method (IDF 20-3: 2004, IDF 20-4: 2001, and IDF 29-1: 2004, respectively) using a Tecator Digestor Auto and Kjeltec 8400 distiller (Foss Electric).

A further 1,000 mL per treatment was skimmed using a Disc Bowl Centrifuge (Armfield Ltd., Ringwood, UK). The milk was heated to $40^{\circ} \mathrm{C}$ in a waterbath and then poured into the bowl section of the centrifuge. After approximately $20 \mathrm{~s}$, the top valve was opened to allow the milk into the separating discs. The skim milk was collected and the cream discarded. The centrifuge was dismantled and all of the components cleaned. Once reassembled, the process was repeated for the other treatment milk samples.

One hundred milliliters of the skim milk per treatment was used for protein composition analysis. Separation of the milk protein fractions was achieved in reverse phase mode using an Agilent Poroshell 300SB C18 column $(2.1 \mathrm{~mm} \times 75 \mathrm{~mm}$; Agilent Technologies 
UK Ltd., Cheshire, UK). The HPLC equipment consisted of an Agilent 1200s with quaternary pump and multi-wavelength detector. Gradient elution and peak detection were performed according to Mounsey and O'Kennedy (2009). The skim milk samples and standards were prepared according to Guyomarc'h et al. (2007) and diluted volumetrically. All CN and whey standards were supplied by Sigma-Aldrich (SigmaAldrich, Vale Road, Arklow, Co. Wicklow, Ireland).

Body weight and BCS were recorded weekly. Body weight was assessed using a portable weighing scale and the Winweigh Software Package (Tru-Test Ltd., Auckland, New Zealand). During weighing, BCS was assessed by an experienced trained observer using the method of Edmonson et al. (1989), where 1 is emaciated and 5 is obese.

Individual cow grass DMI was estimated during wk 4 of the study using the n-alkane technique (Mayes et al., 1986) as modified by Dillon and Stakelum (1989). All cows were dosed twice daily, before milking, for 12 consecutive days with a filter paper bung (Carl Roth, $\mathrm{GmbH}$ and Co. KG, Karlsruhe, Germany) containing $500 \mathrm{mg}$ of dotriacontane (C32). From d 7 of dosing fecal grab samples were collected from each cow twice daily for the remaining $6 \mathrm{~d}$. The fecal grab samples were then bulked (12 $\mathrm{g}$ of each sample collected) and dried for 48 $\mathrm{h}$ in a $40^{\circ} \mathrm{C}$ oven in preparation for chemical analysis.

In conjunction with the fecal collection, the diet of animals was also sampled. Grass representative of that grazed (taking cognizance of the previous day's defoliation height recorded for each treatment) was collected from each treatment grazing area before a.m. grazing on d 6 to 11 (inclusive) of the intake measurement period. Two samples of approximately $250 \mathrm{~g}$ were taken from each treatment grazing area with a Gardena hand shears. Grass silage samples were collected daily from the feed face immediately after the silage was dispensed. Concentrate samples were collected daily from the inparlor feeders.

The n-alkane concentrations (C25-C36) of the feces, grass, grass silage, and concentrate were analyzed using a modification of the method of Mayes et al. (1986), which used direct saponification (Dillon, 1993). The DMI of grass, grass silage, and concentrate were estimated from the concentrations of the n-alkanes $\left(\mathrm{C}_{27}\right.$ $\mathrm{C}_{35}$ ) in the $\mathrm{DM}$ of the feces, grass, grass silage and concentrate, and the daily dosage rate of $\mathrm{C}_{32}$. A leastsquares optimization procedure was used (Microsoft Excel SOLVER, Microsoft Corp., Redmond, WA). This was a modification of the "Eatwhat" method of Dove and Moore (1995). The method minimized the sum of the squared discrepancies for each alkane between the actual fecal n-alkane concentration (corrected for incomplete recovery) and calculated fecal n-alkane concentration in DM as follows:

calculated $F_{i}=$ grass intake $G_{i}+$ grass silage intake $S_{i}$
+ concentrate intake $C_{i}+$ dose $_{i} /$ fecal DM output,

where $F_{i}, G_{i}, S_{i}$, and $C_{i}$ were the respective concentrations of n-alkane $i$ in the feces, grass, grass silage, and concentrate DM, respectively, and Dose ${ }_{i}$ was the amount of n-alkane $i$ in the daily dose. In the above equation, the DMI of grass and grass silage, and the estimation of fecal DM output, were the unknown variables determined using the optimization method. All other parameters were known variables. Dose ${ }_{i}$ was zero for all alkanes except for $\mathrm{C}_{32}$-alkane. The recovery correction factors used to adjust the actual n-alkane concentrations in the DM of the feces were those reported by Dillon (1993). They were $0.618,0.686,0.722,0.769$, $0.777,0.844$, and 0.891 for heptocosane $\left(\mathrm{C}_{27}\right.$-alkane $)$, octacosane $\left(\mathrm{C}_{28}\right.$-alkane $)$, nonacosane $\left(\mathrm{C}_{29}\right.$-alkane $)$, triacontane $\left(\mathrm{C}_{30}\right.$-alkane $)$, hentriacosane $\left(\mathrm{C}_{31}\right.$-alkane $)$, tritriacosane $\left(\mathrm{C}_{33^{-}}\right.$-alkane), and pentatriacontane $\left(\mathrm{C}_{35^{-}}\right.$ alkane), respectively. The recovery factor for $\mathrm{C}_{32}$-alkane was assumed to be the same as that of $\mathrm{C}_{33}$-alkane. The DMI of grass silage by GSH and GSL was estimated using the same least-squares procedure as described above.

Fecal samples were also analyzed for $\mathrm{N}$ concentration using a Leco N Analyzer (Leco FP-528, Leco Corporation, St. Joseph, MI). Fecal N excretion was calculated using the estimated fecal output and the analyzed fecal $\mathrm{N}$ concentration.

Urine $\mathrm{N}$ excretion was determined by subtracting the $\mathrm{N}$ excreted in feces and milk from the total $\mathrm{N}$ intake (van Vuuren et al., 1993).

The efficiency of $\mathrm{N}$ utilization was calculated as $\mathrm{N}$ excreted in milk (protein yield/6.25) divided by total $\mathrm{N}$ intake $\{[\mathrm{N}$ concentration in grass $(\mathrm{n}=\mathrm{CP} / 6.25) \times$ grass DMI] + supplementary feed $\mathrm{N}$ intake (where applicable)\}, assuming a zero $\mathrm{N}$ accretion in the body.

Blood samples were collected from each cow via coccygeal venipuncture in the week before the beginning of the study, during wk 3 and 5 , and in the final week of the study. Blood samples were collected immediately after morning milking (approximately $0830 \mathrm{~h}$ ). Samples were collected into a Vacutainer (BD, Dun Laoghaire, Ireland) containing lithium heparin as an anticoagulant. Samples were immediately centrifuged at $3,000 \times$ $g\left(4^{\circ} \mathrm{C}\right)$ for $10 \mathrm{~min}$. The plasma was decanted and immediately frozen at $-20^{\circ} \mathrm{C}$ before analysis. The blood metabolites analyzed were glucose, NEFA, BHBA, BUN, total protein, and albumin. Analysis was carried out using appropriate kits (glucose, total protein, 
and BUN: ABX Mira, Cedex 4, France; NEFA: Wako Chemicals GmbH, Neuss, Germany; BHBA: Randox Laboratories Ltd., Crumlin, County Antrim, UK; Albumin, Horiba ABX, Montpellier, France) on an ABX Pentra 400 autoanalyzer (ABX Mira).

\section{Statistical Analysis}

All statistical analyses were carried out using mixed models in SAS v9.3 (SAS Institute Inc., Cary, NC). The data for milk yield, solids corrected milk yield, milk solids yield, milk protein concentration, milk fat concentration, milk lactose concentration, milk CN concentration, MUN concentration, BW, BCS, and blood metabolites were analyzed. The respective pre-experimental variables were used as a covariate in the analysis. The fixed factors in the model were experimental week, treatment, and the interaction of treatment and week. Week was the repeated measure. Cow was included as the random effect. The covariance structure with the lowest Akaike information criterion was retained in the final model (compound symmetry).

Composite milk $\mathrm{N}$ fractions, composite milk protein composition, $\mathrm{N}$ intake, fecal $\mathrm{N}$ excretion, urine $\mathrm{N}$ excretion, total $\mathrm{N}$ excretion, and DMI were analyzed using mixed models in SAS v9.3. The model included treatment. No repeated statement or covariance structure was used in the model.

In all cases, statistically significant differences between least squared means were tested using the Tukey test for pairwise comparison of treatment means.

\section{RESULTS}

We found no significant difference in pregrazing herbage mass and pregrazing sward height among treatments. The mean pregrazing herbage mass during the study was (mean $\pm \mathrm{SD}) 2,032 \pm 281 \mathrm{~kg}$ of DM/ha $(>4$ $\mathrm{cm})$ and the pregrazing sward height was (mean $\pm \mathrm{SE}$ ) $12.2 \pm 0.23 \mathrm{~cm}$. Treatment HG (mean $\pm \mathrm{SE} ; 4.53 \pm$ $0.048 \mathrm{~cm}$ ) had a greater postgrazing sward height than all other treatments $(P<0.001)$. Treatments GSL $(4.11$ $\pm 0.048 \mathrm{~cm})$, GCL $(4.03 \pm 0.048 \mathrm{~cm})$, and GSH $(4.02 \pm$ $0.048 \mathrm{~cm}$ ) had a significantly greater postgrazing sward height than LG $(3.77 \pm 0.048 \mathrm{~cm})$. Treatment GSL also had a greater postgrazing sward height than GCH (3.89 $\pm 0.048 \mathrm{~cm}$ ).

The chemical composition of the grass throughout the study is shown is Table 1 and was similar among treatments. The chemical composition of the silage and concentrate offered throughout the study is shown in Table 2.

Grass DMI, supplement DMI, and total DMI are presented in Table 3. A treatment effect on grass DMI

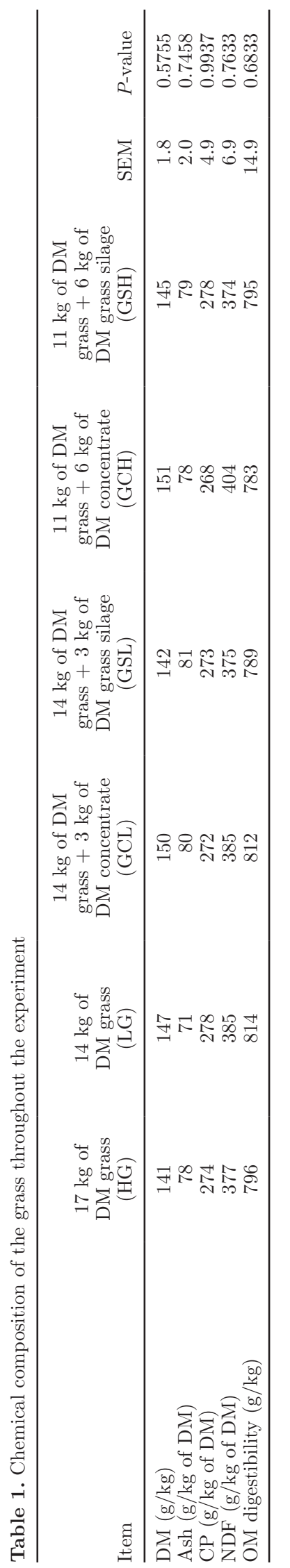

Journal of Dairy Science Vol. 98 No. 8, 2015 
Table 2. Chemical composition of the supplementation offered throughout the experiment

\begin{tabular}{lcc}
\hline Item & Concentrate & $\begin{array}{c}\text { Grass } \\
\text { silage }\end{array}$ \\
\hline $\mathrm{DM}(\mathrm{g} / \mathrm{kg})$ & 900 & 310 \\
$\mathrm{CP}(\mathrm{g} / \mathrm{kg}$ of DM) & 159 & 156 \\
$\mathrm{NDF}(\mathrm{g} / \mathrm{kg}$ of $\mathrm{DM})$ & 83 & 498 \\
Ash $(\mathrm{g} / \mathrm{kg}$ of $\mathrm{DM})$ & 57 & 101 \\
Starch $(\mathrm{g} / \mathrm{kg}$ of $\mathrm{DM})$ & 267 & - \\
$\mathrm{DM}$ digestibility $(\mathrm{g} / \mathrm{kg})$ & - & 705 \\
OM digestibility $(\mathrm{g} / \mathrm{kg})$ & - & 727 \\
\hline
\end{tabular}

$(P<0.001)$ was observed. Treatment GSH had a lower grass DMI than all treatments. The grass DMI of GCH and GSL was lower than that of HG, LG, and GCL. A significant effect of treatment on supplement DMI $(P<$ 0.001) was observed. Treatment GCL and GSL had a similar supplement DMI, which was significantly lower than GCH and GSH. Treatment GCH had a greater supplement DMI than GSH. A significant treatment effect was observed on total DMI. The total DMI of GCH LG, and GCL treatments were similar and greater than GSH. The total DMI of GSL was similar to that of HG, LG, GCL, and GSH.

Milk yield, SCM yield, milk solids yield, milk fat concentration, milk protein concentration, milk lactose concentration, MUN concentration, and milk CN concentration are presented in Figure 1. We detected significant treatment by week interactions in all parameters $(P<0.01)$.

During every week of the experiment, GCH milk yield was significantly greater than LG and HG. During wk 1 to $6, \mathrm{GCH}$ milk yield was greater than GSL. During wk 4 to 6 , GCH milk yield was greater than GSH. During wk 7, GCH milk yield was greater than GCL. During every week of the experiment, GCL milk yield was greater than LG. During wk 1 to 6 , GCL milk yield was greater than HG and GSL. During wk 5 and 6, GCL milk yield was greater than GSH. During wk 1 to 5 of the experiment, GSH milk yield was greater than LG. During wk 1 to 3, GSH milk yield was greater than HG. During wk 3, GSH milk yield was greater than GSL. No significant differences among the HG, LG and GSL treatments were observed. In summary, a treatment effect on milk yield and SCM was present. Treatment GCH and GCL had a significantly higher milk yield than HG, LG, and GSL. Treatment GSH was greater than LG, but similar to the other 4 treatments. Treatments HG, LG, and GSL were similar to one another. Treatment GCL and GCH had a greater SCM than all other treatments.

During every week of the experiment GCH milk solids yield was greater than LG, HG, and GSH. During was greater than GSL and GSH. Total DMI in the HG,

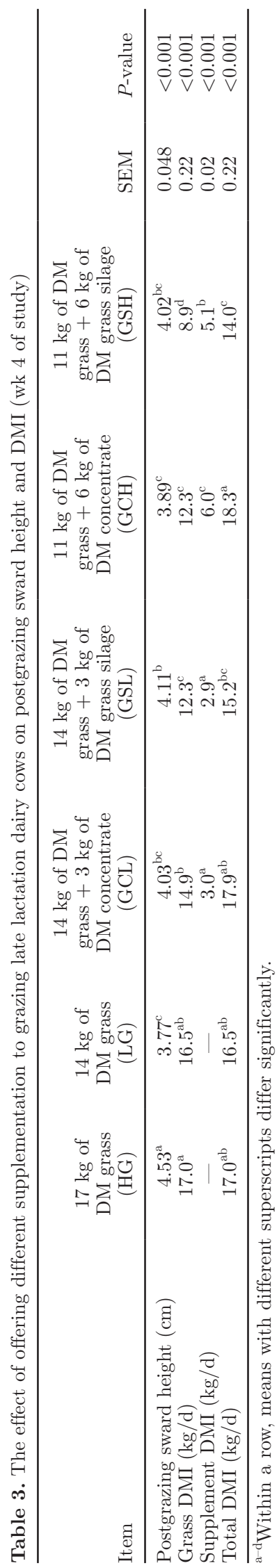

Journal of Dairy Science Vol. 98 No. 8, 2015 

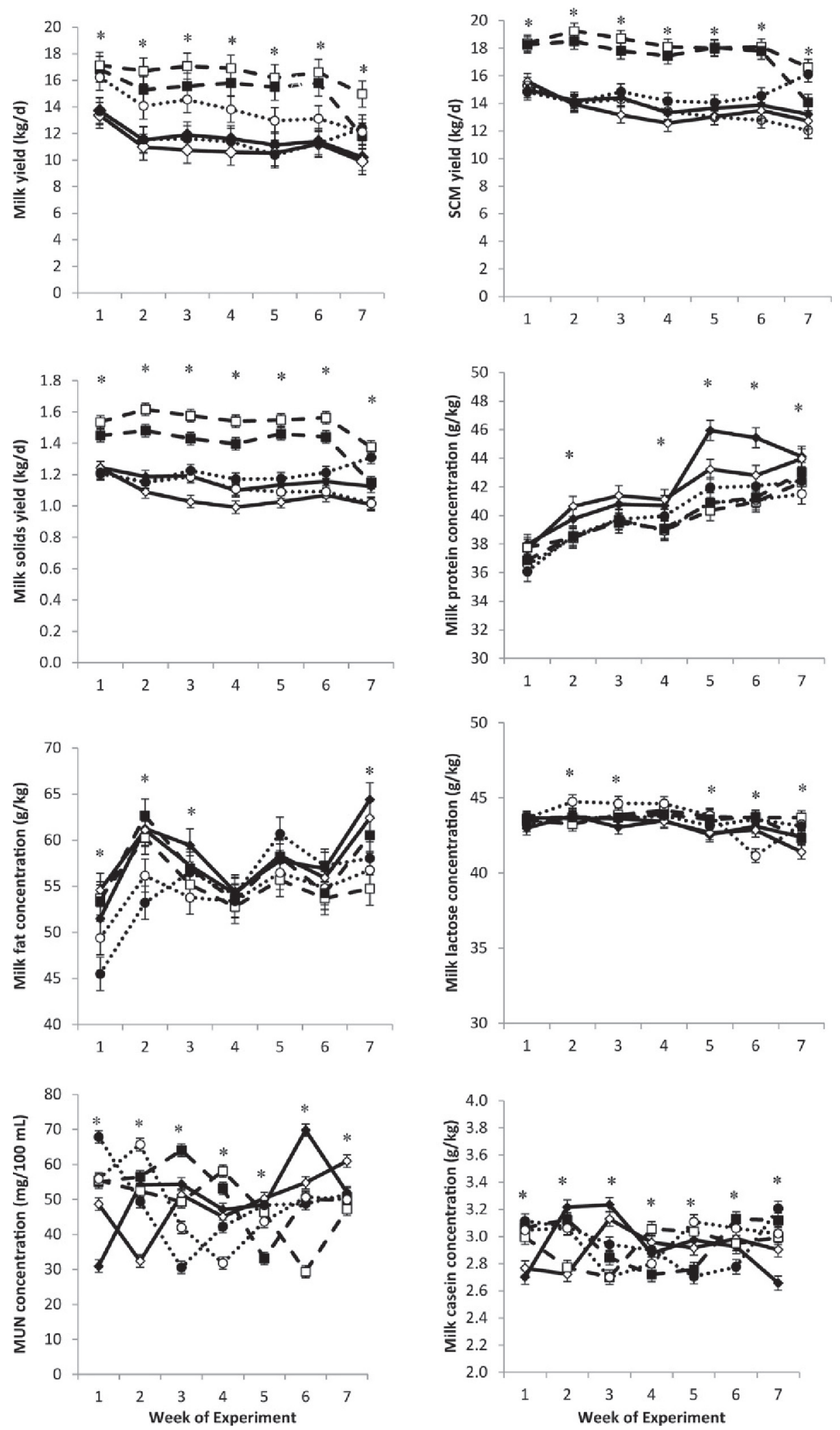

Figure 1. The effect of offering high grass allowance (HG; - - ), low grass allowance (LG; - $\downarrow-)$, grass with low concentrate allowance (GCL; $--\mathbf{-}$ ), grass with low grass silage allowance (GSL; $\cdots \cdots$ ), grass with high concentrate allowance (GCH; - - $\square--$ ), or grass with high silage allowance (GSH; $\cdots \circ \cdots)$ to grazing late lactation dairy cows on milk yield and composition. *Significant differences between treatments during this observation week $(P<0.05)$; error bars indicate standard errors. 
wk 1 to 6 , GCH milk solids yield was greater than GSL. During wk 2, 3, 4, 6, and 7 GCH milk solids yield was greater than GCL. During wk 1 to 7 of the experiment, GCL milk solids yield was greater than LG and GSH. During wk 1 to 6, GCL milk solids yield was greater than HG and GSL. During wk 3 to 7, GSL milk solids yield was greater than LG. During wk 6 and 7, GSL milk solids yield was greater than GSH. During wk 7, GSL milk solids yield was greater than GCL and HG. During wk 7, HG milk solids yield was greater than GSH. During wk 3, 5, and 7, LG milk solids yield was less than HG. During wk 3 and 4, LG milk solids yield was less than GSH. In summary, a treatment effect on milk solids yield was observed. Treatment GCH had a significantly higher milk solids yield than all other treatments. Treatment GCL had a significantly higher milk solids yield than HG, LG, GSL, and GSH. Treatments GSL and HG had similar milk solids yield, which was greater than LG. Treatment GSH had a milk solids yield that was intermediate, and not significantly different, compared with HG, GSL, and LG.

During wk 5 and 6 , the milk protein $\%$ of HG was greater than all other treatments. During wk 2, LG milk protein \% was greater than the milk protein $\%$ of $\mathrm{GCH}$, GCL, GSH, and GSL. During wk 4 and 5, LG milk protein $\%$ was greater than the milk protein $\%$ of $\mathrm{GCH}$, GCL, and GSH. During wk 7, LG and HG milk protein $\%$ was greater than the milk protein \% of GSH. No differences were found among GCH, GCL, GSH, and GSL treatments. In summary, an effect of treatment on milk protein concentration was present. Treatment HG had a greater milk protein concentration than GCH, GSH, GCL, and GSL. Treatment LG had a greater milk protein concentration than GCH, GSH, and GCL (which were similar to each other). Treatment GSL had a milk protein concentration which was intermediate, and not significantly different, compared with LG, GCH, GSH, and GCL.

The treatment by week interaction had a significant effect on milk fat, milk lactose, MUN, and milk CN concentrations, but no consistent differences among treatments were observed.

Composite milk $\mathrm{N}$ fractions are presented in Table 4. We observed a treatment effect on the concentration of total protein $(P<0.01)$, true protein $(P<$ $0.01)$, and $\mathrm{CN}$ protein $(P<0.05)$. Treatment LG had a greater concentration of total protein than GSL, GSH, and GCH. Treatments HG and GCL did not differ significantly compared with any other treatment. The concentration of true protein in the grass-only treatments was significantly greater than GCH and GSH. Treatment GCL and GSL did not differ significantly compared with any other treatment. Casein protein concentration was greater in HG and GSL than in
GCH. Treatments LG, GCL, and GSH were similar to each other, and did not differ compared with any other treatment.

The protein composition of the composite milk samples is presented in Table 5 . We detected that the concentration of $\alpha_{S_{1}}$ CN differed significantly among treatments $(P<0.01)$. The HG treatment had a greater concentration of $\alpha_{\mathrm{S}_{1}} \mathrm{CN}$ than GSH. All other treatments were intermediate and did not differ significantly to HG and GSH. Treatment GSH also had a lower concentration of $\alpha_{\mathrm{S}_{2}} \mathrm{CN}$ than LG $(P<0.05)$. All other treatments were intermediate and did not differ significantly to LG and GSH. The concentration of $\beta-\mathrm{CN}$ was greater in HG and GSL than in LG and GCH $(P<0.01)$. The concentration of $\beta-\mathrm{CN}$ in GCL and GSH did not differ from any of the other treatments. We found a significant treatment effect on the concentration of $\kappa-\mathrm{CN}(P<0.01)$. The concentration of $\kappa-\mathrm{CN}$ in HG was significantly greater than that of GSL. All other treatments were intermediate and did not differ significantly compared with HG and GSL. We observed that the whey proteins ( $\beta-\mathrm{LG}$ and $\alpha$-LA) were both significantly affected by treatment. The concentration of $\beta$-LG in GCL was significantly greater than GCH $(P<0.05)$. We found no other significant differences among treatments in the concentration of $\beta$-LG. Treatments $\mathrm{HG}$ and $\mathrm{GCH}$ had a greater concentration of $\alpha$-LA than GCL $(P<0.01)$. All other treatments were intermediate and did not differ significantly compared with $\mathrm{HG}, \mathrm{GCH}$, and GCL.

Nitrogen utilization efficiency data are presented in Table 6 . We observed a significant effect of treatment on $\mathrm{N}$ intake $(P<0.001)$. Treatments $\mathrm{HG}, \mathrm{LG}$, and GCL had a greater $\mathrm{N}$ intake than GSL and GSH. The $\mathrm{N}$ intake of GCH was greater than GSH. No difference in N intake between GSL and GCH or between GSL and GSH was observed. We found a significant treatment effect on fecal $\mathrm{N}$ excretion $(P<0.01)$. Fecal $\mathrm{N}$ excretion was greater in GCH and GCL than in LG, GSL, and GSH. The fecal N excretion of HG was intermediate and did not differ compared with any other treatment. We detected a significant treatment effect on the excretion of urine $\mathrm{N}(P<0.001)$. The urine $\mathrm{N}$ excretion of HG, LG, and GCL was greater than GSL and GSH. Treatment GCH had a greater urine N excretion than GSH. No difference was found in urine $\mathrm{N}$ excretion between GSL and GCH or between GSL and GSH. The proportion of $\mathrm{N}$ intake that was excreted in the urine and feces was significantly lower in GCH and GSH compared with HG, LG, and GCL $(P<0.001)$. Treatment GSL excreted a similar proportion of $\mathrm{N}$ intake compared with GCL, GCH, and GSH. Treatments $\mathrm{HG}$ and $\mathrm{LG}$ excreted a greater proportion of $\mathrm{N}$ intake than all other treatments. 
SUPPLEMENTATION OF LATE-LACTATION DAIRY COWS
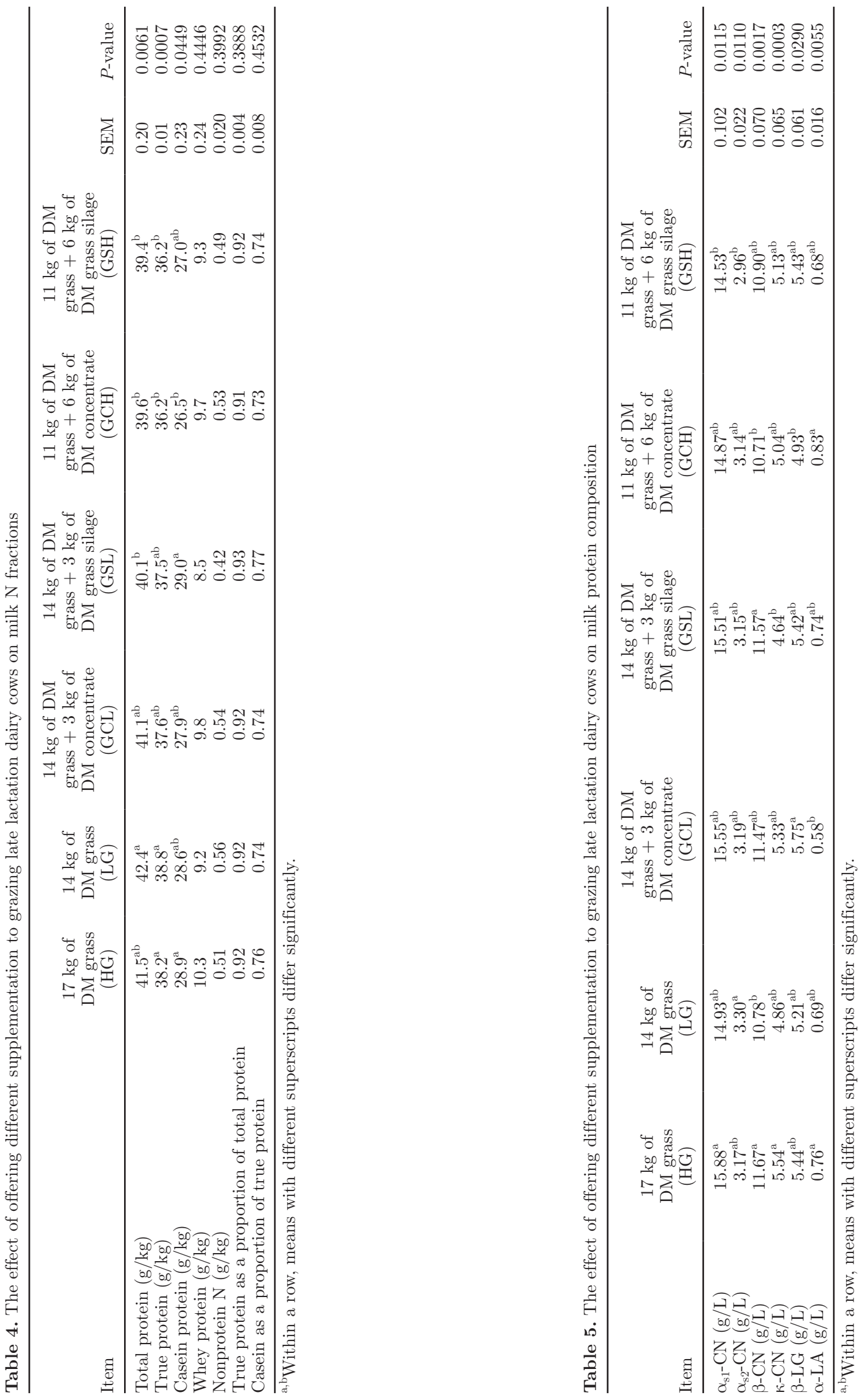

Journal of Dairy Science Vol. 98 No. 8, 2015 
Blood metabolites data are presented in Table 7. We found no significant effects of treatment on total protein concentration or BUN concentration. The concentration of glucose in $\mathrm{HG}$ cows was greater than that of LG and GSH $(P<0.05)$. Treatments GCL, GSL, and $\mathrm{GCH}$ were intermediate and did not differ compared with any other treatment. We observed a significant effect of treatment on NEFA concentration $(P<0.05)$. Cows within the GSL treatment had a significantly greater blood NEFA concentration than GCL, GCH, and GSH. Treatment HG and LG were intermediate and did not differ to any other treatment. We detected a significant treatment effect on blood BHBA concentration $(P<0.01)$. Treatments HG, LG, and GSH had a lower concentration of BHBA than GCH. The BHBA concentration of cows in GCL and GSL were intermediate and did not differ to any other treatment. We also found a significant effect of treatment on blood albumin concentration $(P<0.05)$. Cows within $\mathrm{HG}$, LG, and GCH had a greater concentration of blood albumin than GSH. The GCL and GSL treatments were intermediate and did not differ significantly compared with any other treatment.

We observed no significant effect of treatment on BW and BCS during the experiment. The mean BW of the HG, LG, GCL, GSL, GCH, and GSH treatments was $523,511,520,518,528$, and $512 \pm 15.0 \mathrm{~kg}$, respectively. The mean BW during each week of the experiment (1-7) was 524, 512, 517, 524, 530, 522, and $526 \pm 7.1$ $\mathrm{kg}$, respectively. The mean BCS of HG, LG, GCL, GSL, GCH and GSH was $3.28,3.17,3.22,3.24,3.40$, and 3.26 \pm 0.053 , respectively. The mean BCS during each week of the experiment (1-7) was 3.40, 3.26, 3.26, 3.46, 3.55, 3.26 , and $3.26 \pm 0.029$, respectively.

\section{DISCUSSION}

Grass silage is the most important feed source available to Irish dairy cows after grazed grass (Finneran et al., 2010). Recent grassland management recommendations in Ireland have resulted in more baled grass silage being used as supplementation. This has led to baled grass silage becoming an increasingly important feed source in Ireland. The objective of this study was to investigate the effects of offering different supplementary feeds to grazing spring-calving dairy cows in late lactation on milk yield and composition, NUE, and milk $\mathrm{N}$ fractions.

The grass grazed by the cows on the different treatments was similar, indicated by the similarity in chemical composition. The grazing management was in accordance with that recommended by O'Donovan (2000). Differences in grazing pressure applied by the different treatments were reflected in differences in

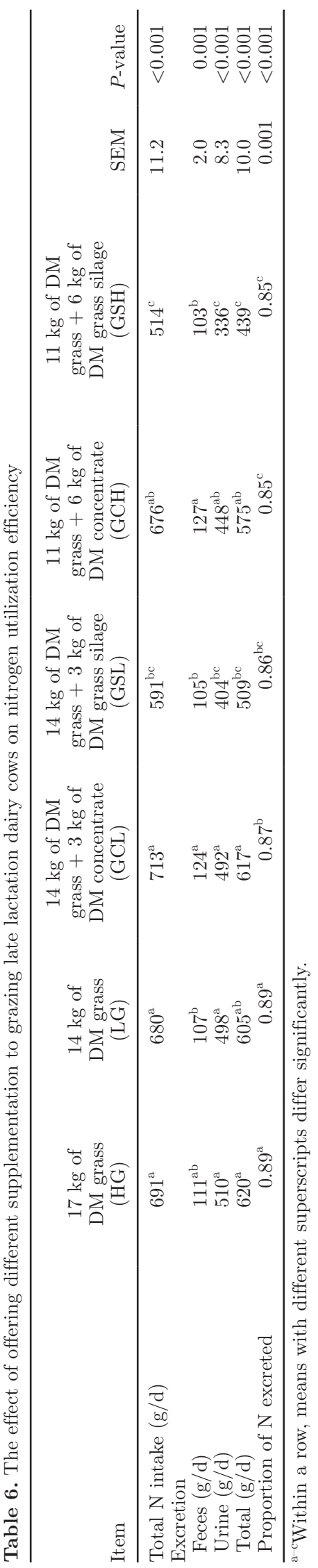


postgrazing sward height. The lower postgrazing sward height in the LG treatment indicated that the grazing pressure was greater than in HG, which had a higher postgrazing sward height. The lower postgrazing sward height was indicative of the lower grass allowance offered to the LG treatment compared with the HG treatment. Offering supplementation such as silage or concentrate reduced the grazing pressure, and therefore increased postgrazing sward height compared with the LG treatment.

\section{Dry Matter Intake and Milk Production}

Grass DMI can be reduced when cows are offered supplementary feeds along with their grass allowance, which is known as substitution rate (SR; Kellaway and Harrington, 2004). Substitution rate is calculated as SR $(\mathrm{kg} / \mathrm{kg})=$ (grass DMI in unsupplemented treatment - grass DMI in supplemented treatment)/supplement DMI. It is therefore possible to discuss SR on the GCL and GSL treatments compared with the LG treatment (all offered $14 \mathrm{~kg}$ of DM $>4 \mathrm{~cm}$ ). It is not possible for $\mathrm{HG}$ to be included in this comparison because the cows on this treatment were offered a different herbage allowance $(17 \mathrm{~kg}$ of DM $>4 \mathrm{~cm})$. Grass, supplement, and animal factors have been identified as being important factors influencing SR and MR (Stockdale, 2000). The factors affecting SR include the amount and type of base feed, the amount and type of supplement offered, and the stage of lactation and production potential of the cow (Baudracco et al., 2010). The type of supplement offered affects SR because different feeds have different fill values (FV; filling effect of a feed in the rumen; Faverdin et al., 2011). The FV of grass silage is greater than that of concentrate. The SR therefore increases when grass silage is used as the supplementary feed compared with using concentrate at the same supplementation rate or compared with an unsupplemented grass diet (Bargo et al., 2003). In the current study, offering $3 \mathrm{~kg}$ of DM grass silage as supplementation to $14 \mathrm{~kg}$ of DM grass caused a SR of $1.45 \mathrm{~kg}$ of DM grass per $\mathrm{kg}$ of grass silage DMI. We found no SR when $3 \mathrm{~kg}$ of DM concentrate was offered as supplementation to $14 \mathrm{~kg}$ of DM grass. This demonstrates that, with a similar grass allowance, the FV of the supplementary feed influences the SR. Stockdale and Trigg (1985) found that when $14.9 \mathrm{~kg}$ of DM grass and $3.6 \mathrm{~kg}$ of DM concentrate was consumed, no substitution of grass by concentrate occurred, which agrees with the current study.

Cows within the HG treatment were offered $17 \mathrm{~kg}$ of DM $>4 \mathrm{~cm}$ and had a postgrazing sward height of $4.5 \mathrm{~cm}$. This resulted in a lower total DMI than offered. Cows within the LG treatment were offered 14 
$\mathrm{kg}$ of DM $>4 \mathrm{~cm}$ and had a postgrazing sward height of $3.8 \mathrm{~cm}$, which resulted in a greater total DMI than offered. The result of this was a similar total DMI in the 2 grass-only treatments. Total DMI was reduced by 10.6 and $17.6 \%$ when 3 or $6 \mathrm{~kg}$ of DM grass silage was offered, respectively, compared with when $17 \mathrm{~kg}$ of DM grass was offered. In comparison, total DMI was increased by 5.3 and $7.6 \%$ when 3 or $6 \mathrm{~kg}$ of DM concentrate was offered, respectively, compared with when $17 \mathrm{~kg}$ of DM grass was offered. The reduction in total DMI with grass silage is due to the greater FV of grass silage compared with concentrate. Bargo et al. (2003) observed that total DMI can be increased by up to $24 \%$ when up to $10 \mathrm{~kg}$ of DM concentrate are included in the diet of grazing dairy cows compared with grass-only diets. A target of supplementary feeding is to increase total DMI. In the case of the current study, total DMI was increased when concentrate was offered as supplementation. Offering $6 \mathrm{~kg}$ of DM of grass silage reduced total DMI. Offering $3 \mathrm{~kg}$ of DM of grass silage also statistically reduced total DMI compared with GCH, but not compared with the grass-only treatments or the GCL treatment.

Energy intake is associated with milk yield and milk solids production (Broderick, 2003). This agrees with the current study because milk yield, milk solids yield, and SCM were greatest on GCH and GCL, which had the highest DMI and likely the highest energy intake due to the energy-dense nature of concentrate.

The MR of the HG treatment was $0.2 \mathrm{~kg}$ of milk $/ \mathrm{kg}$ of extra grass offered (compared with the LG treatment). This is similar to the finding of Delaby et al. (2001) who reported that for grass allowances between 12 and $22 \mathrm{~kg}$ of DM, $5 \mathrm{~kg}$ of DM extra grass consumed would result in a MR of approximately $1 \mathrm{~kg}$ of milk, which is a MR of $0.2 \mathrm{~kg}$ of milk/ $\mathrm{kg}$ of extra grass. As grass allowance increases further, the MR would be expected to decrease (Bargo et al., 2003). The MR of the GSL treatment in the current study was $0.2 \mathrm{~kg}$ of milk $/ \mathrm{kg}$ of grass silage offered. This is lower than that reported by Crosse and Gleeson $(1987 ; 0.39 \mathrm{~kg}$ of milk/kg of grass silage offered) who offered spring-calving dairy cows in late lactation grazed grass supplemented with grass silage. They offered grass silage ad libitum. The grass silage intake was $8.6 \mathrm{~kg}$ of DM. The grass allowance was more restricted than in the current study. The MR of the GCL cows in the current study was $1.4 \mathrm{~kg}$ of milk/ $\mathrm{kg}$ concentrate offered. This is higher than that observed by Delaby et al. (2001) and Burke et al. (2008). Burke et al. (2008) observed a MR of $0.9 \mathrm{~kg}$ of milk/ $\mathrm{kg}$ concentrate consumed when concentrate was used as a supplement for grazing dairy cows. It was reported that a MR of $1 \mathrm{~kg}$ of milk/ $\mathrm{kg}$ of concentrate can be expected provided that the level of concentrate does not exceed
$6 \mathrm{~kg}$ per cow/d (Peyraud et al., 2004). The cause of the increased MR in the current study may, again, be related to the quality of the grass consumed by the cows. A poorer quality base feed would be expected to result in a larger MR (Bargo et al. 2003). These results suggest that further research should be carried out to explore the nutritive value of autumn grass.

During wk 3,5, and 7, the milk solids yield of the LG cows was significantly lower than the HG cows. No significant difference was observed in grass DMI between the treatments in wk 4 , but the increased grazing pressure of the LG cows, demonstrated by a lower postgrazing sward height, may offer an explanation for the reduction in milk solids yield.

A treatment by week effect on milk fat concentration was present, but a consistent treatment effect was not observed. A reduction in milk fat concentration can be caused by changes in rumen fermentation patterns such as a decrease in rumen pH (Plaizier et al., 2008). The significant differences in the current study were predominantly that, during some weeks, the milk fat concentration of HG and LG was greater than GSH and GSL. The use of forage-based supplements would be expected to prevent milk fat depression due to the buffering effect of the forages on rumen $\mathrm{pH}$. The buffering effect is a result of increased saliva production caused by chewing (Andersen et al., 1999). This did not occur. A reduction in milk fat concentration when grass silage was fed has previously been reported, but with no potential explanation offered (Phillips, 1988; O'Brien et al., 1996) and therefore requires further investigation. The rapid degradation in the rumen of rapidly degradable feeds, such as starch-based concentrates, leads to increased concentrations of VFA and a consequent reduction in rumen $\mathrm{pH}$ (Krause and Oetzel, 2006). It was anticipated that the GCH would have the lowest milk fat concentration due to the high proportion of concentrate in the diet and low proportion of fibrous feed in the form of grass. This was only observed in wk 8 when GCH had a lower milk fat concentration than HG. On the GCH diet, two-thirds of DMI was grass, which clearly maintained healthy rumen conditions for the duration of the study.

Milk protein concentrations in GCL, GSL, GCH, and GSH were lower than in HG. Broderick (2003) reported an increase in milk protein concentration when dietary $\mathrm{CP}$ increases from 150 to $167 \mathrm{~g} / \mathrm{kg}$. They showed that further increases in dietary CP to $187 \mathrm{~g} / \mathrm{kg}$ had no further positive effect on milk protein concentration. Dietary CP intake in the current study exceeded requirements on all treatments due to the greater grass $\mathrm{CP}$ concentration than anticipated (average $274 \mathrm{~g}$ of $\mathrm{CP} /$ $\mathrm{kg}$ of DM). The dietary CP concentrations of the HG and LG treatments in the current study were 274 and 
$278 \mathrm{~g} / \mathrm{kg}$ of DM, respectively. The GCL, GSL, GCH, and GSH treatments had a dietary CP concentration of 253, 251, 232, and $234 \mathrm{~g} / \mathrm{kg}$ of DM, respectively. The milk yield of GCL, GSL, and GCH was greater than HG, which may have diluted the milk protein, reducing the concentration compared with the HG treatment.

\section{Milk Nitrogen Fractions and Milk Protein Composition}

Although significant differences were observed among the treatments in the concentration of total and true protein in the composite milk samples, true protein as a proportion of total protein was similar among treatments. The lower true protein concentration in the GCH and GSH treatments can therefore be attributed to the lower concentration of total protein in these treatments. An increased concentration of $\mathrm{CN}$ in milk is important from a processing perspective because it is associated with increased cheese yield (Lucey and Kelly, 1994). Energy intake has been positively associated with both milk total protein concentration (Phillips, 1988) and CN concentration (Kefford et al., 1995). The reduced total and true protein concentration of GSH is therefore unsurprising considering its total DMI was low. The low concentration of true protein and CN protein in GCH was unexpected because it had the greatest total DMI and thus total energy intake.

The concentration of the different proteins within milk largely determines the milk technological properties and nutritional value (Dalgleish, 1993). The 6 major proteins found in bovine milk are $\alpha_{\mathrm{S} 1^{-}} \mathrm{CN}, \alpha_{\mathrm{S}^{-}}$ $\mathrm{CN}, \beta-\mathrm{CN}$, and $\kappa-\mathrm{CN}$, together with the whey proteins $\alpha$-LA and $\beta$-LG. The concentrations of all proteins were within the typical range found in dairy cows as specified by Farrell et al. (2004). Differences existed in the concentration of the different proteins among the treatments. $\alpha_{\mathrm{S}_{1}}$-Casein is the principal component of the CN micelle, which is dispersed as a colloid in milk (Fox and McSweeney, 2003). In general, the treatments that had the highest $\mathrm{CN}$ concentration had the highest $\alpha_{\mathrm{S1}}$-CN concentration (HG and GSL) and those that had the lowest $\mathrm{CN}$ concentration had the lowest $\alpha_{\mathrm{S}_{1}} \mathrm{CN}$ concentration ( $\mathrm{GCH}$ and $\left.\mathrm{GSH}\right)$. Hermansen et al. (1999) reported that the concentration of $\alpha_{\mathrm{S} 1}-\mathrm{CN}$ can be altered due to the supply of urea to the small intestine. The supply of amino acids and urea to the small intestine is largely dependent on the diet, with an increase in dietary $\mathrm{CP}$ and energy among the factors that can increase supply (Hristov et al., 2004). The decreased concentration of $\alpha_{\mathrm{S}_{1}} \mathrm{CN}$ in GSH compared with HG is likely due to the large proportion of a low energy supplementary feed included in the diet of GSH, resulting in GSH having the lowest energy intake. This may have reduced the availability of amino acids for $\mathrm{CN}$ synthesis. $\alpha_{\mathrm{S}_{2}}$-Casein occurs at a lower concentration in bovine milk than $\alpha_{S_{1}-} \mathrm{CN}$, but the 2 are closely linked because when one is reduced, the other is also reduced (Dalgleish and Corredig, 2012). Thus the low total DMI and energy intake exhibited by GSH cows is likely to account for their lower milk $\alpha_{S_{2}}-\mathrm{CN}$ concentration. The concentration of $\beta-\mathrm{CN}$ and $\kappa-\mathrm{CN}$ were highest in HG, but they were not the lowest in GSH. The sample numbers in the analysis of the protein composition and the milk $\mathrm{N}$ fractions of the composite samples were low ( $\mathrm{n}=3$ per treatment). Continued research is needed to fully establish the effects of nutrition on milk $\mathrm{N}$ fractions and protein composition.

The concentration of $\beta-\mathrm{LG}$ was lowest in $\mathrm{GCH}$. $\beta$-Lactoglobulin is the most abundant whey protein, accounting for approximately $58 \%$ of total whey protein (Hogarth et al., 2004). Aleandri et al. (1990) reported a positive association between the concentration of $\beta$-LG and milk fat concentration. Milk fat concentration was significantly reduced in the GCH treatment in wk 8 , but no consistent significant differences among treatments were found. Differences in $\beta$-LG concentration have also been associated with blood albumin concentration (Gray and Mackenzie, 1987). The concentration of blood albumin in GCH was intermediate to the other treatments. Because of the lack of corroborating evidence, the differences in $\beta$-LG among treatments may not be of biological significance. It is desirable to increase the concentration of $\alpha$-LA in bovine milk so that the milk will more closely mimic the protein composition of human milk. This would make it more suitable for processing into infant milk formula (Lien, 2003). During lactation $\alpha$-LA complexes with galactosyletransferase to produce lactose synthase. This is responsible for the production of lactose (Bauman et al., 2006). Milk volume is regulated by lactose (MirzaeiAghsaghali and Fathi, 2012). In the current study, the concentration of $\alpha-\mathrm{LA}$ was greatest in $\mathrm{HG}$ and $\mathrm{GCH}$. Treatment GCH had the highest milk yield of the 6 treatments in the study offering an explanation for the increase in $\alpha$-LA concentration. It is unclear why GCL, which had the second highest milk yield, had the lowest $\alpha-\mathrm{LA}$ concentration.

\section{Blood Metabolites and Nitrogen Utilization Efficiency}

Blood metabolites such as glucose, NEFA, BHBA, total protein, and albumin concentrations can be used as indicators of nutritional stress (LeBlanc, 2010). The concentration of glucose is associated with carbohydrate metabolism (McDonald et al., 2001). Blood glucose concentration in the current study, although significantly different among treatments, was within the 
normal range proposed by Mee and Nolan (1994) and was comparable with the blood glucose concentrations reported by Law et al. (2009). During times of BW and BCS loss, FA may not be completely oxidized in the liver, resulting in an increase in the concentration of BHBA in the blood (LeBlanc, 2010). An increase in $\mathrm{BHBA}$ is more likely to be observed in early lactation due to BW and BCS loss postcalving (McNamara et al., 2003). In late lactation, the desired concentration of NEFA is below $0.4 \mathrm{mmol} / \mathrm{L}$ (Whitaker et al., 1983). The concentration of NEFA in the current study was below this target. The NEFA and BHBA concentrations in all treatments in the current study were within the normal ranges proposed by Mee and Nolan (1994) and were similar to those reported by Law et al. (2009).

The $\mathrm{N}$ intake in the current study was similar to that measured by Burke et al. (2008). In that study grass allowances in the HG treatment $(20 \mathrm{~kg}$ of $\mathrm{DM}$ grass/cow), LG treatment (15 kg of DM grass/cow), and supplemented treatments (15 kg of DM grass/ cow) were greater than in the current study. Grass CP concentration in the current study was greater than in the study by Burke et al. (2008). This accounts for the similarity in $\mathrm{N}$ intake across the 2 studies. According to Tamminga (1992), a large proportion of $\mathrm{N}$ intake in dairy cows is not recovered in milk, with proportionally 0.75 to 0.85 excreted in the feces and urine. As stage of lactation increases, NUE decreases (Castillo, 2001). This means that $\mathrm{N}$ excreted in feces and urine increases. The proportion of $\mathrm{N}$ excreted in the feces and urine in the current study ranged from 0.85 to 0.89 . Given that the current study was conducted using cows in late lactation, with an average DIM of $233 \mathrm{~d}$ when NUE was measured, NUE was expected to be poorer than when NUE was measured on similar animals in early lactation (Reid et al., 2015). Urine is the primary route for $\mathrm{N}$ excretion and can be increased with increasing $\mathrm{N}$ intake (Spek et al., 2013). The $\mathrm{N}$ intake in HG, LG, GCL, and GCH were greatest in the current study, with GSH having the lowest $\mathrm{N}$ intake. This was reflected in the urine excretion because urine $\mathrm{N}$ excretion in $\mathrm{HG}$, LG, GCL, and GCH was the greatest, and GSH had the lowest urine $\mathrm{N}$ excretion. Olmos Colmenero and Broderick (2006) observed that as $\mathrm{N}$ intake increases urine $\mathrm{N}$ excretion also increases. Fecal $\mathrm{N}$ excretion is poorly related to dietary $\mathrm{N}$ intake (Whelan et al., 2012). Fecal N consists largely of endogenous N and undigested feed N (Whelan et al., 2012). The increased fecal $\mathrm{N}$ in the GCL and GCH treatments may be due to an increase in rumen undegradable protein (RUP) as a result of the inclusion of concentrate in the diet. The concentration of RUP was estimated to be greater in the concentrate $(64 \mathrm{~g} / \mathrm{kg}$ of DM) than in the grass (47 g/ $\mathrm{kg}$ of DM; figures from Jarrige, 1989). Nitrogen excreted as a proportion of $\mathrm{N}$ intake was lowest in $\mathrm{GCH}$ and GSH. The milk protein yield of the GCH treatment was greatest, offering an explanation for the increased NUE compared with the grass-only treatments, which had a similar $\mathrm{N}$ intake. The increased NUE in GSH may be attributed to its reduced total $\mathrm{N}$ intake, which reduced the quantity of excess $\mathrm{N}$ to be excreted in urine and feces, compared with the grass-only treatments. The grass-only treatments had the highest proportion of $\mathrm{N}$ intake excreted. The $\mathrm{N}$ intake of the grass-only treatments was high. The milk yield and milk protein yield of the grass-only treatments was low, which may explain why the NUE was lower than GCL, which had a similar N intake, but increased NUE. Higgs et al. (2013) reported that $\mathrm{N}$ intake is the main factor influencing NUE, with an increase in $\mathrm{N}$ intake reducing NUE. The NUE of HG and LG was poorer than the NUE of GSL and GSH. The N intake of $\mathrm{HG}$ and LG was greater than GSL and GSH, resulting in an increase in the proportion of $\mathrm{N}$ intake being excreted. The concentration of BUN is closely related to the concentration of MUN and urine N (Spek et al., 2013). In the current study, BUN and MUN were not significantly different among treatments. This indicates that although differences were present among treatments in NUE, differences in $\mathrm{N}$ excretion were not great enough to affect BUN or MUN concentrations.

\section{CONCLUSIONS}

When grass quality, quantity, or both, are deficient, total DMI can be increased with the use of supplementation. We found that a high MR can be achieved by reducing the SR, resulting in an increase in milk yield and milk solids yield. Offering concentrate as supplementation to late lactation spring-calving dairy cows increased milk yield and milk solids yield compared with cows offered grass silage as supplementation or cows on a grass-only diet. We detected no difference in milk solids yield when supplementing $14 \mathrm{~kg}$ of DM or $11 \mathrm{~kg}$ of DM grass with $3 \mathrm{~kg}$ of DM or $6 \mathrm{~kg}$ of DM concentrate, respectively. We also observed no difference in DMI, milk yield, or milk composition in offering 11 $\mathrm{kg}$ of DM grass and $6 \mathrm{~kg}$ of DM grass silage compared with $14 \mathrm{~kg}$ of DM grass and $3 \mathrm{~kg}$ of DM grass silage. Nitrogen utilization efficiency at the animal level was improved with the addition of supplementary feeds into the grass-based diet. The full life-cycle assessment implications of grass-based dairy cow supplementation strategies on N excretion should, however, be investigated. Offering supplementation reduced the milk total protein concentration, true protein concentration, and CN concentration compared with the grass-only diets. $\alpha_{S_{1}}$ Casein was also highest in the HG treatment. This 
suggests that milk from a grass-only diet may be more suitable for processing, even if milk production is not as high as from supplemented diets.

\section{ACKNOWLEDGMENTS}

The authors thank the Moorepark farm management and staff for their assistance throughout the experiment. The technical assistance of M. Feeney, B. Corrigan, N. Kelly, N. Galvin, and H. Slattery (Teagasc, Moorepark, Fermoy, Co. Cork, Ireland) is also greatly appreciated. The authors thank R. W. Mayes (The Hutton Institute, Craigiebuckler, Aberdeen, Scotland) for his technical work and assistance. The first author was funded by the Teagasc Walsh Fellowship scheme. This study was funded by the Department of Agriculture, Food and the Marine Stimulus Fund (11/sf/309; Dublin, Ireland).

\section{REFERENCES}

Aleandri, R., L. Buttazzoni, J. Schneider, A. Caroli, and R. Davoli. 1990. The effects of milk protein polymorphisms on milk components and cheese-producing ability. J. Dairy Sci. 73:241-255.

Andersen, J. B., J. Sehested, and K. L. Ingvartsen. 1999. Effect of dry cow feeding strategy on rumen $\mathrm{pH}$, concentration of volatile fatty acids and rumen epithelium development. Acta Agric. Scand. 49:149-155.

Bargo, F., L. Muller, E. Kolver, and J. Delahoy. 2003. Invited review: Production and digestion of supplemented dairy cows on pasture. J. Dairy Sci. 86:1-42.

Baudracco, J., N. Lopez-Villalobos, C. Holmes, and K. Macdonald. 2010. Effects of stocking rate, supplementation, genotype and their interactions on grazing dairy systems: A review. N. Z. J. Agric. Res. 53:109-133.

Bauman, D., I. Mather, R. Wall, and A. Lock. 2006. Major advances associated with the biosynthesis of milk. J. Dairy Sci. 89:12351243.

Broderick, G. A. 2003. Effects of varying dietary protein and energy levels on the production of lactating dairy cows. J. Dairy Sci. 86:1370-1381.

Burke, F., M. A. O'Donovan, J. J. Murphy, F. P. O'Mara, and F. J. Mulligan. 2008. Effect of pasture allowance and supplementation with maize silage and concentrates differing in crude protein concentration on milk production and nitrogen excretion by dairy cows. Livest. Sci. 114:325-335.

Castillo, A. 2001. Improving nitrogen utilisation in dairy cows. $\mathrm{PhD}$ Thesis. University of Reading, UK.

Crosse, S., and P. Gleeson. 1987. Supplementation of autumn grass with silage and concentrates for grazing dairy cows in late lactation. Isr. J. Agric. Res. 26:69-75.

Dalgleish, D. G. 1993. The enzymatic coagulation of milk. Pages 69100 in Cheese: Chemistry, Physics and Microbiology. P. F. Fox, ed. Springer, New York, NY.

Dalgleish, D. G., and M. Corredig. 2012. The structure of the casein micelle of milk and its changes during processing. Annu. Rev. Food Sci. Technol. 3:449-467.

Delaby, L., J. Peyraud, and R. Delagarde. 2001. Effect of the level of concentrate supplementation, herbage allowance and milk yield at turn-out on the performance of dairy cows in mid lactation at grazing. Anim. Sci. 73:171-181.

Dijkstra, J., O. Oenema, J. van Groenigen, J. Spek, A. van Vuuren, and A. Bannink. 2013. Diet effects on urine composition of cattle and $\mathrm{N}_{2} \mathrm{O}$ emissions. Animal 7:292-302.
Dillon, P. 1993. The use of n-alkanes as markers to determine intake, botanical composition of available or consumed herbage in studies of digesta kinetics of dairy cows. PhD. Thesis, University College Dublin, Ireland.

Dillon, P., and G. Stakelum. 1989. Herbage and dosed alkanes as a grass measurement technique for dairy cows. Isr. J. Agric. Res. $28: 104$.

Dove, H., and A. D. Moore. 1995. Using a least-squares optimization procedure to estimate botanical composition based on the alkanes of plant circular wax. Crop Pasture Sci. 46:1535-1544.

Edmonson, A., I. Lean, L. Weaver, T. Farver, and G. Webster. 1989 A body condition scoring chart for Holstein dairy cows. J. Dairy Sci. 72:68-78.

Farrell, H. Jr., R. Jimenez-Flores, G. Bleck, E. Brown, J. Butler, L. Creamer, C. Hicks, C. Hollar, K. Ng-Kwai-Hang, and H. Swaisgood. 2004. Nomenclature of the proteins of cows' milk-Sixth revision. J. Dairy Sci. 87:1641-1674.

Faverdin, P., C. Baratte, R. Delagarde, and J. Peyraud. 2011. GrazeIn: A model of herbage intake and milk production for grazing dairy cows. 1. Prediction of intake capacity, voluntary intake and milk production during lactation. Grass Forage Sci. 66:29-44.

Finneran, E., P. Crosson, P. O'Kiely, L. Shalloo, D. Forristal, and M. Wallace. 2010. Simulation modelling of the cost of producing and utilising feeds for ruminants on Irish farms. J. Farm Manage. 14:95-116.

Fox, P., and P. L. H. McSweeney. 2003. Advanced Dairy Chemistry. Bd. 1. Proteins. Vol. 1. Springer, New York, NY.

Gray, R., and D. Mackenzie. 1987. Effect of plane of nutrition on the concentration and yield of whey proteins in bovine milk. N. Z. J. Dairy Sci. 22:157-165.

Guyomarc'h, F., O. Mahieux, M. Renan, M. Chatriot, V. Gamerre, and M. H. Famelart. 2007. Changes in the acid gelation of skim milk as affected by heat-treatment and alkaline $\mathrm{pH}$ conditions. Lait 87:119-137.

Hermansen, J., S. Ostersen, C. Justesen, and O. Aaes. 1999. Effects of dietary protein supply on caseins, whey proteins, proteolysis and renneting properties in milk from cows grazing clover or $\mathrm{N}$ fertilized grass. J. Dairy Res. 66:193-205.

Higgs, R., A. Sheahan, K. Mandok, M. Van Amburgh, and J. Roche. 2013. The effect of starch-, fiber-, or sugar-based supplements on nitrogen utilization in grazing dairy cows. J. Dairy Sci. 96:38573866.

Hogarth, C. J., J. L. Fitzpatrick, A. M. Nolan, F. J. Young, A. Pitt, and P. D. Eckersall. 2004. Differential protein composition of bovine whey: A comparison of whey from healthy animals and from those with clinical mastitis. Proteomics 4:2094-2100.

Hristov, A., R. Etter, J. Ropp, and K. Grandeen. 2004. Effect of dietary crude protein level and degradability on ruminal fermentation and nitrogen utilization in lactating dairy cows. J. Anim. Sci. 82:3219-3229.

Jarrige, R. 1989. Ruminant Nutrition: Recommended Allowances and Feed Tables. John Libbey Eurotext, Paris, France.

Kefford, B., M. P. Christian, B. J. Sutherland, J. J. Mayes, and C. Grainger. 1995. Seasonal influences on Cheddar cheese manufacture: Influence of diet quality and stage of lactation. J. Dairy Res. 62:529-537.

Kellaway, R., and T. Harrington. 2004. Feeding Concentrates: Supplements for Dairy Cows. Landlinks Press, Melbourne, Australia.

Kennedy, E., M. O'Donovan, J. P. Murphy, L. Delaby, and F. O'Mara. 2005. Effects of grass pasture and concentrate-based feeding systems for spring-calving dairy cows in early spring on performance during lactation. Grass Forage Sci. 60:310-318.

Krause, K. M., and G. R. Oetzel. 2006. Understanding and preventing subacute ruminal acidosis in dairy herds: A review. Anim. Feed Sci. Technol. 126:215-236.

Law, R., F. Young, D. Patterson, D. Kilpatrick, A. Wylie, and C. Mayne. 2009. Effect of dietary protein content on animal production and blood metabolites of dairy cows during lactation. J. Dairy Sci. 92:1001-1012.

LeBlanc, S. 2010. Monitoring metabolic health of dairy cattle in the transition period. J. Reprod. Dev. 56:S29-S35. 
Lien, E. L. 2003. Infant formulas with increased concentrations of

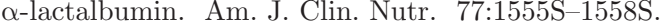

Lucey, J., and J. Kelly. 1994. Cheese yield. Int. J. Dairy Technol. $47: 1-14$.

Mayes, R., C. Lamb, and P. M. Colgrove. 1986. The use of dosed and herbage n-alkanes as markers for the determination of herbage intake. J. Agric. Sci. 107:161-170.

McDonald, P., R. A. Edwards, J. F. D. Greenhalgh, and C. A. Morgan. 2001. Animal Nutrition. 6th ed. Pearsons Education, New York, NY.

McEniry, J., P. Forristal, and P. O'Kiely. 2011. Factors influencing the conservation characteristics of baled and precision-chop grass silages. Ir. J. Agric. Food Res. 50:175-188.

McNamara, S., J. Murphy, M. Rath, and F. O'Mara. 2003. Effects of different transition diets on energy balance, blood metabolites and reproductive performance in dairy cows. Livest. Prod. Sci. 84:195-206.

Mee, J. and M. Nolan. 1994. Summer mini-metabolic profile of 50 spring-calving dairy herds. Teagasc, Moorepark Research and Development Division Research Report. pp. 40-41.

Mirzaei-Aghsaghali, A., and H. Fathi. 2012. Lactose in ruminants feeding: A review. Ann. Biol. Res. 3:645-650.

Morgan, D., and G. Stakelum. 1987. The prediction of the digestibility of herbage for dairy cows. Isr. J. Agric. Res. 26:23-34

Mounsey, J. S., and B. T. O'Kennedy. 2009. Stability of $\beta$-lactoglobulin/ micellar casein mixtures on heating in simulated milk ultrafiltrate at $\mathrm{pH}$ 6.0. Int. J. Dairy Technol. 62:493-499.

O'Brien, B. 2008. Milk quality handbook-Practical steps to improve milk quality. In Moorepark Dairy Levy Update. B. O'Brien, ed. Moorepark Dairy Production Research Centre, Cork, Ireland.

O'Brien, B., S. Crosse, and P. Dillon. 1996. Effects of offering a concentrate or silage supplement to grazing dairy cows in late lactation on animal performance and on milk processability. Ir. J. Agric. Food Res. 35:113-125.

O'Donovan, M. 2000. The relationship between the performance of dairy cows and grassland management on intensive dairy farms in Ireland. PhD Thesis. University College Dublin, Ireland.

Olmos Colmenero, J. J., and G. A. Broderick. 2006. Effect of dietary crude protein concentration on milk production and nitrogen utilization in lactating dairy cows. J. Dairy Sci. 89:1704-1712.

Peyraud, J., R. Mosquera-Losada, and L. Delaby. 2004. Challenges and tools to develop efficient dairy systems based on grazing: How to meet animal performance and grazing management. Grassland Science in Europe 9:373-384.
Phillips, C. 1988. The use of conserved forage as a supplement for grazing dairy cows. Grass Forage Sci. 43:215-230.

Plaizier, J., D. Krause, G. Gozho, and B. McBride. 2008. Subacute ruminal acidosis in dairy cows: The physiological causes, incidence and consequences. Vet. J. 176:21-31.

Reid, M., M. O'Donovan, C. T. Elliott, J. S. Bailey, C. J. Watson, S. T. J. Lalor, B. Corrigan, M. A. Fenelon, and E. Lewis. 2015. The effect of dietary crude protein and phosphorus on grass-fed animal production, nutrient status and milk heat stability. J. Dairy Sci. 98:517-531

Spek, J., A. Bannink, G. Gort, W. Hendriks, and J. Dijkstra. 2013. Interaction between dietary content of protein and sodium chloride on milk urea concentration, urinary urea excretion, renal recycling of urea, and urea transfer to the gastrointestinal tract in dairy cows. J. Dairy Sci. 96:5734-5745.

Stockdale, C. 2000. Levels of pasture substitution when concentrates are fed to grazing dairy cows in northern Victoria. Anim. Prod. Sci. 40:913-921.

Stockdale, C., and T. Trigg. 1985. Effect of pasture allowance and level of concentrate feeding on the productivity of dairy cows in late lactation. Anim. Prod. Sci. 25:739-744.

Sutton, J., K. Aston, D. Beever, and M. Dhanoa. 1996. Milk production from grass silage diets: Effects of high-protein concentrates for lactating heifers and cows on intake, milk production and milk nitrogen fractions. Anim. Sci. 62:207-215.

Tamminga, S. 1992. Nutrition management of dairy cows as a contribution to pollution control. J. Dairy Sci. 75:345-357.

Tyrrell, H., and J. Reid. 1965. Prediction of the energy value of cow's milk. J. Dairy Sci. 48:1215-1223.

Van Soest, P. J., J. B. Robertson, and B. A. Lewis. 1991. Methods for dietary fiber, and non-starch polysaccharides in relation to animal nutrition. J. Dairy Sci. 74:3583-3597.

van Vuuren, A., C. Van der Koelen, H. Valk, and H. De Visser. 1993 Effects of partial replacement of ryegrass by low protein feeds on rumen fermentation and nitrogen loss by dairy cows. J. Dairy Sci 76:2982-2993.

Whelan, S., K. Pierce, C. McCarney, B. Flynn, and F. Mulligan. 2012. Effect of supplementary concentrate type on nitrogen partitioning in early lactation dairy cows offered perennial ryegrass-based pasture. J. Dairy Sci. 95:4468-4477.

Whitaker, D., J. Kelly, and E. Smith. 1983. Subclinical ketosis and serum beta-hydroxybutyrate levels in dairy cattle. Br. Vet. J. 139:462-463. 